\title{
Dedicator of Cytokinesis Protein 1
}

National Cancer Institute

\section{Source}

National Cancer Institute. Dedicator of Cytokinesis Protein 1. NCI Thesaurus. Code C26116.

Dedicator of cytokinesis protein 1 (1865 aa, $215 \mathrm{kDa}$ ) is encoded by the human DOCK1 gene. This protein is involved in phagocytosis, apoptosis and signaling. 